\title{
A new nematode species, Chromadorina tangaroa sp. nov. (Chromadorida:Chromadoridae) from the hull of a research vessel, New Zealand
}

\author{
Daniel Leduc ${ }^{\text {Corresp. } 1}$ \\ ${ }^{1}$ National Institute of Water and Atmospheric Research, Wellington, New Zealand \\ Corresponding Author: Daniel Leduc \\ Email address: Daniel.Leduc@niwa.co.nz
}

Chromadorina is a globally distributed, largely marine nematode genus frequently found on a variety of organisms, including macro- and microalgae and crustaceans, as well as artificial substrates such as settlement plates and ship hulls. Here, Chromadorina tangaroa sp. nov. is described from filamentous seaweed growing on the hull of RV Tangaroa anchored in Wellington, North Island of New Zealand. It is characterized by body length 763-1086 microns, and pore of secretory-excretory system located at or near level of teeth. Males have spicules with rounded capitulum followed by a narrower shaft and blade tapered distally, a gubernaculum as long as the spicules, and three cup-shaped precloacal supplements, and females are characterized by a cuticularized prevulvar pad, vagina located at $46-48 \%$ of body length from anterior, and vagina anteriorly directed.

Chromadorina tangaroa sp. nov. is the first species of the genus to be described from New Zealand, but it is unclear whether it is native to the region because it may have dispersed as part of ship hull biofouling communities. Long-distance transport of nematodes through ship hull biofouling may be a common occurrence, but too little is known about the occurrence of nematodes on ship hulls to gauge the potential effect of shipping on nematode species distributions. 
1 A new nematode species, Chromadorina tangaroa sp. 2 nov. (Chromadorida: Chromadoridae) from the hull of 3 a research vessel, New Zealand

6 Daniel Leduc

8 National Institute of Water and Atmospheric Research, Wellington, New Zealand 9

10 Corresponding Author:

11 Daniel Leduc

12301 Evans Bay Parade, Wellington, 6021, New Zealand

13 Email address: Daniel.Leduc@niwa.co.nz 


\section{Abstract}

Chromadorina is a globally distributed, largely marine nematode genus frequently found on a variety of organisms, including macro- and microalgae and crustaceans, as well as artificial substrates such as settlement plates and ship hulls. Here, Chromadorina tangaroa sp. nov. is described from filamentous seaweed growing on the hull of $R V$ Tangaroa anchored in Wellington, North Island of New Zealand. It is characterized by body length 763-1086 $\mu \mathrm{m}$, and pore of secretory-excretory system located at or near level of teeth. Males have spicules with rounded capitulum followed by a narrower shaft and blade tapered distally, a gubernaculum as long as the spicules, and three cup-shaped precloacal supplements, and females are characterized by a cuticularized prevulvar pad, vagina located at 46-48\% of body length from anterior, and vagina anteriorly directed. Chromadorina tangaroa sp. nov. is the first species of the genus to be described from New Zealand, but it is unclear whether it is native to the region because it may have dispersed as part of ship hull biofouling communities. Long-distance transport of nematodes through ship hull biofouling may be a common occurrence, but too little is known about the occurrence of nematodes on ship hulls to gauge the potential effect of shipping on nematode species distributions.

\section{Introduction}

Vessel hulls are colonized by a wide variety of sessile and mobile organisms ranging from microscopic prokaryotes and unicellular eukaryotes to large invertebrates and macroalgae. These biofouling communities (i.e., accumulations of organisms on submerged artificial surfaces) are sometimes transported over large distances, which can lead to the introduction of non-indigenous organisms in new environments where they may establish new populations and potentially impact local ecological communities (Hewitt et al. 2009, Gallardo et al. 2016). Most of the literature on biofouling has so far focused on relatively large, macrofaunal-sized organisms, as well as microorganisms (Dang \& Lovell 2000, Zardus et al. 2008, Farrapeira et al. 2011). Limited information is available on meiofaunal organisms such as nematodes (Fonseca-Genevois et al. 2006, Chan et al. 2016, von Ammon et al 2018), even though they are common epibionts and arguably the most numerous animals in shallow sedimentary environments worldwide (Giere 1993). Nematodes have very limited active dispersal abilities, but their small size allows them to be passively transported by currents into the water column (Shanks \& Walters 1997, Boeckner et 
44 al. 2009), or as epibionts on sea turtle carapaces and drifting macroalgae (Arroyo et al. 2006, 45 Corrêa et al. 2014). These transport pathways are thought to largely explain the cosmopolitan distribution of some nematode and other meiofaunal taxa (the so-called "meiofauna paradox"; Giere 1993). Long-distance transport of nematodes is also likely to occur through both biofouling and ballast slurry sediments (Radziejewska et al. 2006, Sutherland \& Levings 2013), but little is known about the occurrence of nematodes on ship hulls and the potential effect of shipping on nematode species distributions.

Hard surfaces such as rocks and artificial structures do not provide adequate substrates for nematode colonization (Heip et al. 1985); once they are colonized by biofilm-forming microorganisms and/or habitat-forming macroalgae and invertebrates, however, they constitute a suitable substrate for a range of epibiotic nematodes (Jensen 1984, Kito \& Nakamura 2001, Fonseca-Genevois et al. 2006, Majdi et al. 2011). Species of the nematode genus Chromadorina Filipjev, 1918 are found living on a variety of other organisms, including macroalgae (Chromadorina laeta (de Man, 1876) Micoletzky, 1924, C. obtusa Filipjev, 1918, C. epidemos Hopper \& Meyers, 1967) (Filipjev, 1918, Hopper \& Meyers 1967), vascular plants (C. epidemos Hopper \& Meyers, 1967, C. erythrophthalma (Schneider, 1906) Wieser, 1954) (Hopper \& Meyers 1967, Jensen 1979, 1984), periphyton (C. hiromii Kito \& Nakamura, 2001, C. viridis (Linstow, 1876) Wieser, 1954, C. bioculata (Schultze in Carus, 1857) Wieser, 1954) (Andrássy 1962, Kito \& Nakamura 2001), and the gill cavity of spider crabs (C. majae Wieser, 1968) and crayfish (C. astacicola (Schneider, 1932) Wieser, 1954) (Wieser 1968, Schneider 1932). Chromadorina has also been recorded on artificial settlement plates (Fonseca-Genevois et al. 2006, von Ammon et al. 2018) and ship hulls (Chan et al. 2016). Most species are marine, except for a few which are found in lakes ( $C$. astacicola), groundwater $(C$. bercziki) or both freshwater and brackish waters (C. bioculata and $C$. viridis). Here, we describe a new Chromadorina species recovered from filamentous seaweed growing on the hull of $R V$ Tangaroa anchored in Wellington, North Island of New Zealand.

\section{Materials \& Methods}

Samples of macroalgae were collected by divers from the hull of $R V$ Tangaroa while anchored at Burnham Wharf in Wellington Harbour on 10 November 2019. The macroalgal material 
74 75

containing nematodes was fixed in $10 \%$ buffered formalin. Nematodes were manually sorted from the algal material using a dissecting microscope $(\times 50$ magnification $)$ and transferred to glycerol and mounted onto permanent slides (Somerfield \& Warwick, 1996).

Measurements were obtained using an Olympus BX53 compound microscope with cellSens Standard software. All measurements are in $\mu \mathrm{m}$, and all curved structures are measured along the arc. The terminology used for describing the arrangement of morphological features such as setae follows Coomans (1979). Type specimens are held in the NIWA Invertebrate Collection (Wellington), and the National Nematode Collection of New Zealand (Auckland).

\section{Abbreviations:}

a: body length/maximum body diameter

b: body length/pharynx length

c: body length/tail length

c': tail length/anal or cloacal body diameter

cbd: corresponding body diameter

$\mathrm{L}$ : total body length; $\mathrm{n}$, number of specimens

$\mathrm{V}$ : vulva distance from anterior end of body

$\% \mathrm{~V}: \mathrm{V} /$ total body length $\times 100$

The electronic version of this article in Portable Document Format (PDF) will represent a published work according to the International Commission on Zoological Nomenclature (ICZN), and hence the new names contained in the electronic version are effectively published under that Code from the electronic edition alone. This published work and the nomenclatural acts it contains have been registered in ZooBank, the online registration system for the ICZN. The ZooBank LSIDs (Life Science Identifiers) can be resolved and the associated information viewed through any standard web browser by appending the LSID to the prefix http://zoobank.org/. The LSID for this publication is: urn:lsid:zoobank.org:pub:5DC49B25-C878-4FBA-A74A$7 \mathrm{BE} 2 \mathrm{~F} 61 \mathrm{E} 31 \mathrm{AB}$. The online version of this work is archived and available from the following digital repositories: PeerJ, PubMed Central and CLOCKSS. 
101

102

103

104

105

106

107

108

109

110

111

112

113

114

115

116

117

118

119

120

121

122

123

124

125

14

2

\section{Systematics}

Order Chromadorida Chitwood, 1933

Family Chromadoridae Filipjev, 1917

Subfamily Chromadorinae Filipjev, 1917

Genus Chromadorina Filipjev, 1918

Generic diagnosis: (Modified from Tchesunov (2014)) Homogeneously punctated cuticle with transverse rows of punctations, no lateral differentiation. Amphideal fovea when visible located near level of cephalic setae, transverse slit-like, unispiral, spiral, cryptocircular or loop-shaped. Buccal cavity with three equal teeth or with dorsal tooth slightly larger than ventrosublateral teeth. Ocelli and cup-shaped precloacal supplements may be present. Tail conical or conico-cylindrical with conspicuous spinneret.

$$
\text { Type species: Chromadorina obtusa Filipjev, } 1918
$$

(1)

Remarks: Previous diagnoses state that when visible, the amphideal fovea is slit-like (Platt \& Warwick 1988, Tchesunov 2014). However, several species, including $C$. erythrophthalma (Schneider, 1906) Wieser, 1954, C. salina Belogurov, 1978, C. supralittoralis Lorenzen, 1969, and C. tangaroa sp. nov., have a unispiral, spiral cryptocircular, or loop-shaped amphideal fovea. Venekey et al. (2019) et al. provided a list of 27 valid Chromadorina species.

Chromadorina tangaroa sp. nov.

Figs. 1-3, Table 1

urn:1sid:zoobank.org:act:5E11A50E-6120-42E4-9836-F2C11D7A02A0 
Type locality: Hull of $R V$ Tangaroa (stern), which at the time of sampling was berthed at Burnham wharf in Wellington Harbour, North Island of New Zealand (41.3135 ${ }^{\circ} \mathrm{S}, 174.8106$ $\left.129{ }^{\circ} \mathrm{E}\right)$. NNCNZ 3331) and four paratype females (NIWA 139244, NNCNZ 3332), collected on 10 November 2019.

Measurements: See Table 1 for detailed measurements.

Description: Male. Body colourless in glycerin preparations, cylindrical, tapering slightly towards anterior extremity. Homogeneously punctated cuticle, with transverse striations approximately $1 \mu \mathrm{m}$ apart and interspersed with transverse rows of punctations; lateral differentiation absent. Short somatic setae, $3 \mu \mathrm{m}$ long, sparsely distributed throughout body. Cephalic region blunt, slightly rounded, with relatively well-developed lip region. Inner and outer labial sensilla inconspicuous. Four cephalic setae, 0.3-0.5 cbd long. One or two pairs of sublateral cervical setae present on each side of body, approximately 1.5 cephalic body diameters from anterior extremity. Pigment spots not observed. Amphideal fovea spiral, with 1.5 turns and transversely oval outline, at level of cephalic setae, sometimes difficult to distinguish. Buccal cavity with funnel-shaped pharyngostome; one solid dorsal tooth and two solid, slightly smaller ventrosublateral teeth. Pharynx muscular, not swollen anteriorly, lumen not cuticularized or only slightly cuticularized; conspicuous oval-shape posterior bulb with plasmatic interruptions. Nerve ring located at $55-60 \%$ of pharynx length from anterior. Cardia small, surrounded by intestine. Secretory-excretory system with elongated renette cell, 43-69 $\times$ 8-14 $\mu \mathrm{m}$, and small accessory cell, $12-19 \times 7-11 \mu \mathrm{m}$, both located well posterior to pharynx; pore located far anteriorly at or near level of teeth. 

intestine. Mature sperm cells globular, 9-11 × 6-10 $\mu \mathrm{m}$, with granular nuclei. Spicules paired, equal, slightly ventrally curved, capitulum rounded, narrow shaft and blade gradually tapering distally; gubernaculum slightly ventrally curved, about as long as spicules, with relatively wide, rounded proximal portion, narrow middle portion, and tapering distal portion. Three small, cupshaped precloacal supplements present, beginning 5-8 $\mu \mathrm{m}$ anterior to cloacal opening and situated 8-13 $\mu \mathrm{m}$ apart. Precloacal seta not observed. Tail conical, curved ventrally, with few sparsely distributed sublateral setae, $3 \mu \mathrm{m}$ long; three large caudal glands and well-developed spinneret.

Females. Similar to males, but with slightly lower values of "a" and longer tail.

Reproductive system with two opposed, reflexed ovaries; anterior ovary situated to the right of intestine and posterior ovary situated to the left of intestine. Mature eggs 48-51 $\times 24-32 \mu \mathrm{m}$. Vulva not cuticularized, situated slightly anterior to mid-body, not at right angle with body surface but pointing posteriorly; constrictor muscle present. Vagina anteriorly directed. Prevulvar pad present, consisting of area of slightly thicker cuticle with coarse striations located on slightly to conspicuously raised ventral region immediately anterior to vulva. Vaginal glands not observed.

Diagnosis: Chromadorina tangaroa sp. nov. is characterized by body length 763-1086 $\mu \mathrm{m}$, cephalic setae 0.3-0.5 cbd long, spiral amphid with 1.5 turns and 20-33\% cbd wide, pore of secretory-excretory system located far anteriorly at or near level of teeth. Males spicules with rounded capitulum followed by a narrower shaft and blade tapered distally, gubernaculum as long as spicules, with wide, rounded proximal portion, narrow middle portion, and tapering distal portion, and three cup-shaped precloacal supplements. Females with prevulvar pad, vagina located at $46-48 \%$ of body length from anterior, and vagina anteriorly directed.

Differential diagnosis: In addition to the new species, there are four Chromadorina species which possess two or three precloacal supplements: C. obtusa Filipjev, 1918, C. paradoxa Timm, 1961, C. demani Inglis, 1962, and C. micoletzkyi Inglis, 1962. The new species 
182 can be differentiated from C. obtusa, C. paradoxa, and C. micoletzkyi by the position of the

183 secretory-excretory pore, which is located well posterior to the buccal cavity but anteriorly to the 184 nerve ring in C. paradoxa and C. micoletzkyi, and posterior to the nerve ring in C. obtusa

185 (versus at level of teeth in C. tangaroa sp. nov.). The new species can also be differentiated from 186 C. paradoxa by the shorter body length (0.76-1.09 versus $1.3 \mathrm{~mm})$, lower ratio of "a" (20-29 187 versus 37 in C. paradoxa), structure of the posterior pharyngeal bulb (simple versus double in $C$. 188 paradoxa), longer spicules (32-39 versus $26 \mu \mathrm{m}$ in C. paradoxa), gubernaculum shape (rounded 189 versus tapering proximal portion in C. paradoxa), and shorter male tail (3.4-3.7 versus 6.7 190 cloacal body diameters in C. paradoxa), from C. micoletzkyi by the longer body length (0.761911.09 versus $0.57-0.66 \mathrm{~mm}$ in C. micoletzkyi) and higher ratio of "b" (6-8 versus $<6$ in $C$. 192 micoletzkyi), and from C. obtusa by the longer spicules (32-39 versus $30 \mu \mathrm{m})$, higher ratio of "a" 193 (20-29 versus 17-19 in C. obtusa), and number of precloacal supplements (three versus two 194 supplements in C. obtusa). The position of the secretory-excretory pore in C. demani is not 195 known, but the new species differs from the latter by the longer body length (0.76-1.10 versus 196 0.63-0.72 $\mathrm{mm}$ in C. demani), shorter cephalic setae (0.3-0.5 versus 0.7 cbd in C. demani), 197 relative size of the ventrosulateral teeth (almost the same size as dorsal tooth versus 198 conspicuously smaller than dorsal tooth in $C$. demani), position of the vulva (46-48 versus 51$19955 \%$ in C. demani), and shape of the spicules (elongated and straight capitulum versus short and 200 swollen capitulum in C. demani). Chromadorina tangaroa sp. nov. is the first species of the 201 genus to possess a prevulvar pad, although it is conceivable that this feature may have been 202 missed in previous species descriptions.

Etymology: The species is named after $R V$ Tangaroa, on the hull of which the type specimens were found.

Remarks: Specimens were found amongst filamentous brown (Ectocarpales) and green 208 (Chaetomorpha) macroalgae during the survey of $R V$ Tangaroa hull on 10 November 2019. The following invertebrate taxa were also encountered: solitary tunicates, tubeworms, hydroids (Ectopleura and Obelia spp.), the native barnacle Austrominius modestus, the native bivalves 
211 Perna canaliculus and Mytilus galloprovincialis, and four bryozoans - the non-indigenous

212 species Cryptosula pallasiana and Watersipora subatra and two species of uncertain identity, 213 viz. Electa oligopora and Celleporaria sp.

214

215

Discussion

216

Chromadorina tangaroa sp. nov. is the first species of the genus to be described from New Zealand. Although the specimens were originally collected from Wellington Harbour, the population found on the hull of $R V$ Tangaroa may have originated from another location in New Zealand, or even overseas. The vessel's movement in the four months prior to sampling include voyages to Hikurangi Margin off the east coast of New Zealand's North Island, off Campbell Island in the Southern Ocean, and included a three-day long anchorage in Dunedin on the southeast coast of New Zealand's South Island. However, during this four-month period the vessel spent over four weeks anchored in Wellington Harbour, which makes it the most likely origin for the hull population.

225

It seems likely that nematode taxa such as Chromadorina which preferentially occur on

227

228

229

230

231

232

233

234

235

236

237

238 239

macroalgal substrates are transported between ports by shipping. It has been suggested that some cosmopolitan nematode species have been transported outside their native range following the accidental introduction of their macroalgal habitat in new environments (Kim et al. 2019). To date, the genera Graphonema Cobb, 1898, Prochromadora Filipjev, 1922 (family Chromadoridae Filipjev, 1917), and Halomonhystera Andrássy, 2006 (family Monhysteridae de Man, 1876) are the only other nematode genera (beside Chromadorina) that have so far been identified from ship biofouling assemblages (Chan et al. 2016). Like Chromadorina, these taxa are often associated with attached and drifting macroalgae or artificial substrates (Derycke et al. 2007, Perez-Garcia et al. 2015, Kim et al. 2019). Transport by ballast slurries may also occur; the limited data available to date suggest that they contain nematode assemblages more typical of sedimentary environments with genera such as Desmodora de Man 1889, Sphaerolaimus Bastian, 1865, and Leptolaimus de Man, 1876 having so far been identified (Radziejewska et al. 2006).

The present study provides the second record of Chromadorina on the hull of a vessel. Chan et al. (2016) demonstrated that Chromadorina erythrophthalma populations on the hull of 
242 military ships can survive long distance transits (1000s of kilometres covering over 10 degrees of

243 latitude) from Halifax (eastern Canada) to the Arctic (Nanisivik). A study using high-throughput 244 sequencing methods identified the presence of Chromadorina on settlement plates deployed in a

245 New Zealand marina (von Ammon et al. 2018). Another study showed an unidentified

246 Chromadorina species to be an early colonizer of artificial settlement plates off the coast of

247 Brazil (Fonseca-Genevois et al. 2006). Experiments have shown that Chromadorita tenuis

248 (Schneider, 1906) Filipjev, 1922 (family Chromadoridae) shows a marked preference for

249 macroalgae over sediments, and actively swims several centimetres to colonise macroalgal

250 substrates in response to chemical cues (Jensen 1981). It appears likely that similar habitat

251 preference and behavior are present in Chromadorina species, but no evidence is yet available to

252 test this hypothesis.

253

254

\section{Conclusions}

255

256

257

258

259

260

261

262

263

264

265

266

267

268

269

270

271

272

Chromadorina tangaroa sp. nov. is the first species of the genus to be described or recorded from New Zealand, but it is unclear whether it is native to the region because it may have dispersed as part of ship hull biofouling communities. Overall, the potential for shipping to act as dispersal vector for nematodes across ports and oceans remains largely unstudied. The accidental introduction of nematodes to new environments may be a relatively common occurrence, which could explain the cosmopolitan distribution of some species. Nematodes need to be included in studies of ship hull biofouling communities and in biosecurity surveys to gain further insights into the potential effect of shipping on the distribution of nematode species. Although environmental DNA metabarcoding offers a very useful tool for the identification of nematodes from hull samples, incomplete molecular reference datasets limit the ability to identify species or even genera (Holovachov et al. 2017). Furthermore, additional molecular methods will be required to accurately identify describe patterns of genetic connectivity (Darling et al. 2012).

\section{Acknowledgements}

Funding was provided by NIWA's Coasts and Oceans Centre Research Programme 'Marine Biological Resources'. I thank Roberta D'Archino, Kate Neill, and Wendy Nelson for providing the nematode specimens, Sarah Allen for survey information, and Dennis Gordon for providing 
273 identification of hull fauna. I am grateful to Anna Demchy for obtaining primary literature, to

274 Vadim Mokievsky for translating Russian text, and the three reviewers for providing

275 constructive criticisms on the manuscript.

276

277

\section{References}

278

279

280

281

282

283

284

285

286

287

288

289

290

291

292

293

294

295

296

297

298

299

300

301

302

303

304

305

306

307

308

309

310

Andrássy I. 1962. Nematoden aus dem Ufergrundwasser der Donau von Bratislava bis Budapest. Archiv fur Hydrobiologie 27:91-117.

Andrássy I. 2006. Halomonhystera, a new genus distinct from Geomonhystera Andrássy, 1981 (Nematoda: Monhysteridae). Meiofauna Marina 15:11-24.

Arroyo NL, Aarnio K, Bonsdorff E. 2006. Drifting algae as a means of re-colonizing defaunated sediments in the Baltic Sea. A short-term microcosm study. Hydrobiologia 554:83.

Bastian HC. 1865. Monograph of the Anguillulidae, or free Nematoids, marine, land, and freshwater; with descriptions of 100 new species. The Transactions of the Linnean Society of London 15:73-184.

Belogurov OI. 1978. [Study of free-living nematodes from the intertidal zone of the Shikotan Island.] In: Zhivotnyi i rasti-tel'nyi mir shel'fovykh zon Kuril'skikh Ostrovov. Moscow, USSR, "Nauka”, pp. 139-148.

Boeckner MJ, Sharma J, Proctor HC. 2009. Revisiting the meiofauna paradox: dispersal and colonization of nematodes and other meiofaunal organisms in low- and high-energy environments. Hydrobiologia 62:91-106.

Carus JV 1857. Icones zootomicae, erste Halfte: Die wirbellosen Thiere. Leipzig: W. Engelmann, 1-4.

Chan FT, MacIsaac HJ, Bailey SA. 2016. Survival of ship biofouling assemblages during and after voyages to the Canadian Arctic. Marine Biology 163:250.

Chitwood BG. 1933. A revised classification of the Nematoda. The Journal of Parasitology 20:115-148.

Cobb NA. 1898. Australian free-living marine nematodes. Proceedings of the Linnaean Society of New South Wales 23: 383-407 
311 Coomans A. 1979. Addendum I. A proposal for a more precise terminology of the body regions

312 in the nematode. Annales de la Societee Royale Zoologique de Belgique 108:115-117.

313

314

315

316

317

318

319

320

321

322

323

324

325

326

327

328

329

330

331

332

333

334

335

336

337

338

339

340

341

342

343

344

345

346

347

348

349

350
Correa GVV, Ingels J, Valdes YV, Fonseca-Genevois VG, Parrapeira CMR, Santos GAP. 2014. Diversity and composition of macro- and meiofaunal carapace epibionts of the hawksbill sea turtle (Eretmochelys imbricate Linnaeus, 1822) in Atlantic waters. Marine Biodiversity 44:391401.

Dang H, Lovell CR. 2000. Bacterial primary colonization and early succession on surfaces in marine waters as determined by amplified rRNA gene restriction analysis and sequence analysis of 16S rRNA genes. Applied and Environmental Microbiology 66:467475.

Darling JA, Herborg LM, Davidson IC. 2012. Intracoastal shipping drives patterns of regional population expansion by an invasive marine invertebrate. Ecology and Evolution 2:2557-2566.

de Man JG. 1876. Onderzoekingen over vrij in de aarde levende Nematoden. Tijdschrift Nederlandsche Dierkundig Vereeiging 2:78-196.

de Man JG. 1889. Espèces et genres nouveaux de Nématodes libres de la mer du Nord et de la Manche. Mémoires de la Societe Zoologique de France 2:1-10.

Derycke S, Van Vynckt R, Vanaverbeke J, Vincx M, Moens T. 2007. Colonization patterns of Nematoda on decomposing algae in the estuarine environment: Community assembly and genetic structure of the dominant species Pellioditis marina. Limnology and Oceanography 52:992-1001.

Farrapeira CMR, Tenorio DO, do Amaral FD. 2011. Vessel biofouling as an inadvertent vector of benthic invertebrates. Marine Pollution Bulletin 62:832-839.

Filipjev IN. 1917. Un nématode libre nouveau de la mer Caspienne, Chromadorissa gen. nov. Chromadoridae, Chromadorini) Zoologichesky Zhurnal 2:24-30. (Translated from Russian).

Filipjev IN. 1918. Free-living marine nematodes of the Sevastopol area. Transactions of the Zoological Laboratory and the Sevastopol Biological Station of the Russian Academy of Sciences. Series II, Jerusalem: Israel Program for Scientific Translations, N4, (Issue I \& II) (Translated from Russian).

Filipjev IN. 1922. Encore sur les Nématodes libres de la mer Noire. Trudy Stavropol'skogo Sel'skokhoziaistvennogo Instituta 1:83-184. 
351

352

353

354

355

356

357

358

359

360

361

362

363

364

365

366

367

368

369

370

371

372

373

374

375

376

377

378

379

380

381

382

383

384

385

386

387

388

389

390
Fonseca-Genevois V, Somerfield PJ, Neves MHB, Coutinho R, Moens T. 2006. Colonization and early succession on artificial hard substrata by meiofauna. Marine Biology 148:1039-1050.

Gallardo B, Clavero M, Sánchez MI, Vilà M. 2016. Global ecological impacts of invasive species in aquatic ecosystems. Global Change Biology 22:151-163.

Giere O. 1993. Meiobenthology, the Microscopic Fauna in Aquatic Sediments. Springer-Verlag, Berlin.

Heip C, Vincx M, Vranken G. 1985. The ecology of marine nematodes. Oceanography and Marine Biology Annual Reviews 23:399-489.

Hewitt CL, Gollasch S, Minchin D. 2009. The vessel as a vector - Biofouling, ballast water and sediments. In: Rilov G, Crooks JA. Eds. Biological invasions in marine ecosystems: Ecological management, and geographic perspectives. Berlin: Springer-Verlag Berlin and Heidelberg GmbH \& Co., 117-131.

Holovachov O, Haenel Q, Bourlat SJ, Jondelius U. 2017. Taxonomy assignment approach determines the efficiency of identification of OTUs in marine nematodes. Royal Society Open Science 4:170315.

Hopper BE, Meyers SP. 1967. Folicolous marine nematodes on turtle grass, Thalassia testudinum König, in Biscayne Bay, Florida. Bulletin of Marine Science 17:471-517.

Inglis WG. Marine nematodes from Banyuls-Sur-Mer: with a review of the genus Eurystomina. Bulletin of the British Museum of Natural History (Zoology) 8:209-287.

Jensen P. 1979. Nematodes from the brackish waters of the southern archipelago of Finland. Phytal species. Annales Zoologici Fennici 16:281-285.

Jensen P (1981) Phytochemical sensitivity and swimming behavior of the free-living marine nematode Chromadorita tenuis. Marine Ecology Progress Series 4:203-206.

Jensen P. 1984. Ecology of benthic and epiphytic nematodes in brackish waters. Hydrobiologia 108:201-217.

Kim HG, Hawkins LE, Godbold JA, Oh CW, Rho HS, Hawkins SJ. 2019. Comparison of nematode assemblages associated with Sargassum muticum in its native range in South Korea and as an invasive species in the English Channel. Marine Ecology Progress Series 611:95-110.

PeerJ reviewing PDF | (2020:03:47101:1:0:NEW 28 Apr 2020) 
391

392

393

394

395

396

397

398

399

400

401

402

403

404

405

406

407

408

409

410

411

412

413

414

415

416

417

418

419

420

421

422

423

424

425

426

427

428

429
Kito K, Nakamura T. 2001. A new species of Chromadorina (Nematoda: Chromadoridae) discovered in a laboratory aquarium. Species Diversity 6:111-116.

Linstow OV. 1876. Helminthologische Beobachtungen. Archiv für Naturgeschichte 42:1-18.

Lorenzen S. 1969. Freilebende Meeresnematoden aus dem Schlickwatt und den Salzwiesen der Nordseeküste. Veröffentlichungen des Instituts für Meeresforschung in Bremerhaven 11:195238.

Majdi N, Transpurger W, Boyer S, Mialet B, Tackx M, Fernandez R, Gehner S, Ten-Hage L, Buffan-Dubau E. 2011. Response of biofilm-dwelling nematodes to habitat changes in the Garonne River, France: influence of hydrodynamics and microalgal availability. Hydrobiologia 673:229-244.

Micoletzky H. 1924. Letzter bericht über freilebende nematoden aus Suez. Sitzungsberichten der Akademie der Wissenschaften in Wien, Mathem-naturw 133:137-179.

Perez-Garcia JA, Ruiz-Abierno A, Armenteros M. 2015. Does morphology of host marine macroalgae drive the ecological structure of epiphytic meiofauna? Journal of Marine Biology \& Oceanography 4:1

Platt HM, Warwick RM. 1988. Free living nematodes Part I. British Chromadorids. Synopses of the British Fauna (New Series), Kermack DM, Barnes RSK eds. Published for The Linnean Society of London and The Estuarine and Brackish-Water Sciences Association by E.J. Brill / Dr W. Backhuys. No. 38, 502p.

Radziejewska T, Gruska P, Rokicka-Praxmajer J. 2006. A home away from home: a meiobenthic assemblage in a ship's ballast water tank sediment. Oceanologia 48:259-265.

Schneider G. 1906. Beitrag zur Kenntnis der im Uferschlamm des Finnischen Meerbusens freilebenden Nematoden. Acta Societatis pro Fauna et Flora Fennica 27:1-40.

Schneider W. 1932. Nematoden aus der Kiemenhöhle des Flußkrebses. Archiv fur Hydrobiologie 24:629-636.

Shanks AL, Walters K. 1997. Holoplankton, meroplankton, and meiofauna associated with marine snow. Marine Ecology Progress Series 156:75-86.

PeerJ reviewing PDF | (2020:03:47101:1:0:NEW 28 Apr 2020) 
430 Somerfield PJ, Warwick RM. 1996. Meiofauna in Marine Pollution Monitoring Programmes: a 431 Laboratory Manual. Lowestoft: Ministry of Agriculture, Fisheries and Food.

432

433

434

435

436

437

438

439

440

441

442

443

444

445

446

447

448

449

450

451

452

453

454

455

456

457

458

459

460

461

462

463
Sutherland TF, Levings CD. 2013. Quantifying non-indigenous species in accumulated ballast slurry residuals (swish) arriving at Vancouver, British Columbia. Progress in Oceanography 115:211-218.

Tchesunov AV. 2014. Order Chromadorida Chitwood, 1933. Pp. 373-398 in: Schmidt-Rhaesa A. ed. Handbook of Zoology Volume 2: Nematoda. Hamburg: De Gruyter, xv + 759 pp.

Timm RW. 1961. The marine nematodes pf the Bay of Bengal. Proceedings of the Pakistan Academy of Science 1:25-88.

Venekey V, Gheller PF, MC, Kandratavicius N, Cunha BP, Vilas-Boas AC, Fonseca G, Maria TF. 2019. The state of the art of Chromadoridae (Nematoda, Chromadorida) a historical review, diagnoses and comments about valid and dubious genera and a list of valid species. Zootaxa 4578:1-67.

von Ammon U, Wood SA, Laroche O, Tait L, Lavery S, Inglis G, Pochon X. 2018. The impact of artificial substrate on marine bacterial and eukaryotic biofouling assemblages: A highthroughput sequencing analysis. Marine Environmental Research 133:57-66.

Vranken G, Tire C, Heip C. 1989. Effect of temperature and food on hexavalent chromium toxicity to the marine nematode Monhystera disjuncta. Marine Environmental Research 27:127136.

Wieser W. 1954. Reports of the Lund University Chile expedition 1948-1949: II. Chromadoroidea. Lunds Universitets Arsskrift 50:1-148.

Wieser W. 1968. Chromadorina astacicola (Schneider, 1932) und Chromadorina majae n. sp., zwei mit Decapoden vergesellschaftete Nematoden. Thalassia Jugoslavica 4:39-43.

Zardus JD, Nedved BT, Huang Y, Tran C, Hadfield MG. 2008. Microbial biofilms facilitate adhesion in biofouling invertebrates. Biological Bulletin 214:91-98. 


\section{Figure captions}

465 Figure 1. Chromadorina tangaroa sp. nov. (A) Female anterior body region. (B) Male paratype 466 cephalic region. (C) Male holotype cephalic region. (D) Female cephalic region. (E) Female 467 paratype posterior body region. (F) Male holotype posterior body region. Scale bar: $35 \mu \mathrm{m}(\mathrm{A})$, $46816 \mu \mathrm{m}(\mathrm{B}, \mathrm{C}$ and $\mathrm{D}), 30 \mu \mathrm{m}(\mathrm{E})$ and $25 \mu \mathrm{m}(\mathrm{F})$.

469

470

Figure 2. Chromadorina tangaroa sp. nov. (A) Entire paratype female. (B) Entire holotype

471 male. Scale bar: $125 \mu \mathrm{m}$ (A and B).

472

473 Figure 3. Chromadorina tangaroa sp. nov. Light micrograph of paratype female showing vulva 474 (V), prevulvar pad (PVP) and posterior ovary (PO). Scale bar: $10 \mu \mathrm{m}$. 


\section{Table 1 (on next page)}

Table 1. Morphometrics of Chromadorina tangaroa sp. nov.

Table 1. Morphometrics (in microns, mean (range)) of Chromadorina tangaroa sp. nov. a, body length/maximum body diameter; $b$, body length/pharynx length; $c$, body length/tail length; $c^{\prime}$, tail length/anal or cloacal body diameter; cbd, corresponding body diameter; $L$, total body length; $n$, number of specimens; NO, not observed; $\mathrm{V}$, vulva distance from anterior end of body; \%V, V/total body length $\times 100$ 
Table 1. Morphometrics ( $\mu \mathrm{m}$, mean (range)) of Chromadorina tangaroa sp. nov. a, body length/maximum body diameter; $\mathrm{b}$, body length/pharynx length; c, body length/tail length; c', tail length/anal or cloacal body diameter; cbd, corresponding body diameter; L, total body length; n, number of specimens; NO, not observed; $\mathrm{V}$, vulva distance from anterior end of body; \%V, V/total body length $\times$ 100

\begin{tabular}{|c|c|c|c|c|c|c|c|c|}
\hline & $\begin{array}{l}\text { Males } \\
\text { Holotype }\end{array}$ & $\begin{array}{l}\text { Paratype } \\
1\end{array}$ & $\begin{array}{l}\text { Paratype } \\
2\end{array}$ & $\begin{array}{l}\text { Paratype } \\
3\end{array}$ & $\begin{array}{l}\text { Females } \\
\text { Paratype } \\
1\end{array}$ & $\begin{array}{l}\text { Paratype } \\
2\end{array}$ & $\begin{array}{l}\text { Paratype } \\
3\end{array}$ & $\begin{array}{l}\text { Paratype } \\
4\end{array}$ \\
\hline $\mathrm{L}$ & 991 & 763 & 1002 & 847 & 1086 & 910 & 938 & 917 \\
\hline $\mathrm{a}$ & 29 & 24 & 25 & 26 & 23 & 24 & 24 & 20 \\
\hline $\mathrm{b}$ & 8 & 6 & 8 & 7 & 8 & 7 & 7 & 7 \\
\hline $\mathrm{c}$ & 9 & 8 & 9 & 8 & 8 & 7 & 7 & 8 \\
\hline$c^{\prime}$ & 3.4 & 3.6 & 3.7 & 3.5 & 5.0 & 5.1 & 5.1 & 4.5 \\
\hline Head diam. at cephalic setae & 12 & 12 & 14 & 13 & 13 & 14 & 15 & 14 \\
\hline Head diam. at amphids & 12 & NO & NO & 4 & 16 & NO & 3 & 15 \\
\hline Length of sub-cephalic setae & $2-5$ & $4-5$ & $2-3$ & $2-5$ & $4-5$ & $3-5$ & $3-6$ & $3-5$ \\
\hline Length of cephalic setae & 6 & $5-6$ & 6 & 5 & 5 & 5 & 5 & 5 \\
\hline Amphid height & 2 & $\mathrm{NO}$ & NO & 2 & 3 & NO & 2 & 2 \\
\hline Amphid width & 4 & $\mathrm{NO}$ & NO & 4 & 4 & $\mathrm{NO}$ & 3 & 5 \\
\hline Amphid width/cbd (\%) & 33 & NO & NO & 31 & 25 & NO & 20 & 33 \\
\hline Amphid from anterior end & 1 & $\mathrm{NO}$ & NO & 2 & 5 & NO & 3 & 2 \\
\hline Nerve ring from anterior end & 70 & 72 & 70 & 68 & 77 & 74 & 73 & 69 \\
\hline Nerve ring cbd & 27 & 26 & 27 & 27 & 31 & 28 & 27 & 29 \\
\hline Pharynx length & 128 & 121 & 128 & 121 & 135 & 131 & 132 & 125 \\
\hline Pharyngeal bulb diam. & 28 & 25 & 28 & 26 & 30 & 27 & 27 & 28 \\
\hline Pharynx cbd at base & 31 & 29 & 33 & 31 & 36 & 33 & 32 & 33 \\
\hline Max. body diam. & 34 & 32 & 40 & 33 & 47 & 38 & 39 & 45 \\
\hline Spicule length & 36 & 32 & 36 & 32 & - & - & - & - \\
\hline Gubernaculum length & 35 & 32 & 35 & 32 & - & - & - & - \\
\hline Cloacal/anal body diam. & 33 & 28 & 33 & 30 & 29 & 24 & 25 & 27 \\
\hline Tail length & 111 & 101 & 111 & 105 & 144 & 123 & 127 & 122 \\
\hline $\mathrm{V}$ & - & - & - & - & 495 & 427 & 454 & 419 \\
\hline$\% \mathrm{~V}$ & - & - & - & - & 46 & 47 & 48 & 46 \\
\hline Vulval body diam. & - & - & - & - & 41 & 38 & 39 & 44 \\
\hline
\end{tabular}




\section{Figure 1}

Drawings of body regions Chromadorina tangaroa sp. nov.

Figure 1. Chromadorina tangaroa sp. nov. (A) Female anterior body region. (B) \& (C) Male cephalic region. (D) Female cephalic region. (E) female posterior body region. (F) Male posterior body region. Scale bar: 35 microns $(A), 16$ microns ( $B, C$ and $D), 30$ microns $(E)$ and 25 microns (F). 


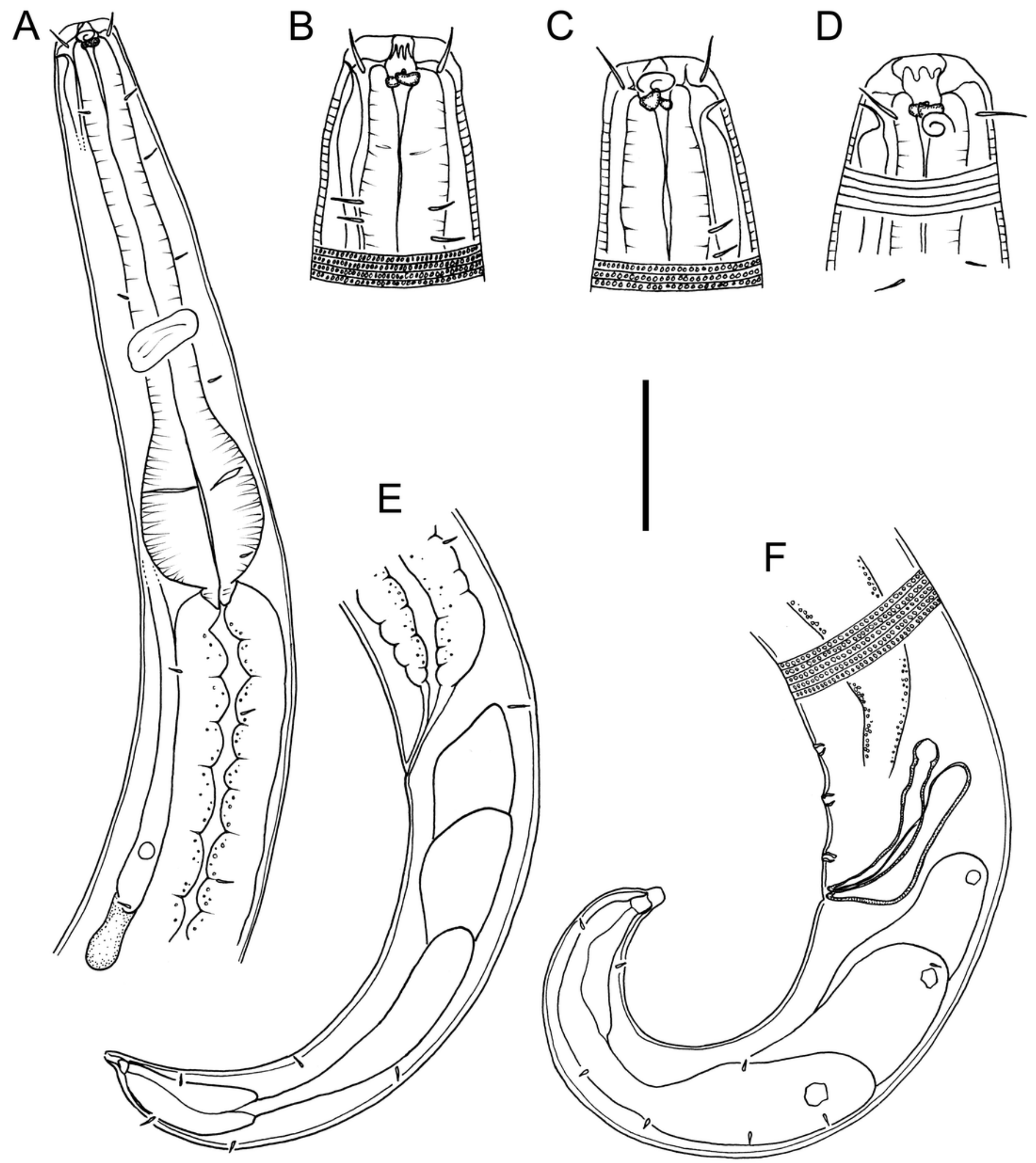


Figure 2

Drawings of entire male and female Chromadorina tangaroa sp. nov.

Figure 2. Chromadorina tangaroa sp. nov. (A) Entire female. (B) Entire male. Scale bar: 125 microns ( $A$ and $B$ ). 


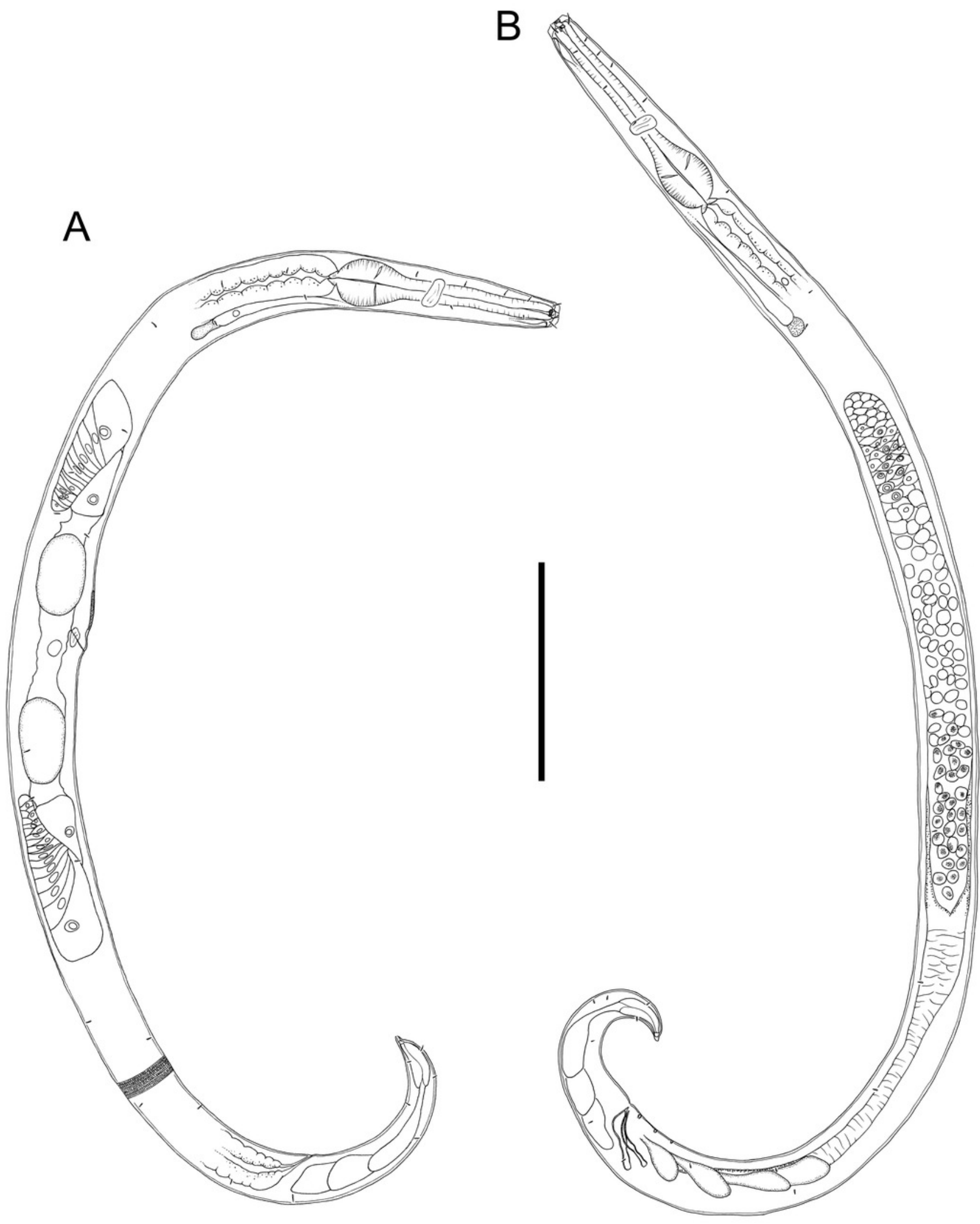


Figure 3

Light micrograph of Chromadorina tangaroa sp. nov.

Figure 3. Chromadorina tangaroa sp. nov. Light micrograph of female showing vulva (V), prevulvar pad (PVP) and posterior ovary (PO). Scale bar: 10 microns. 


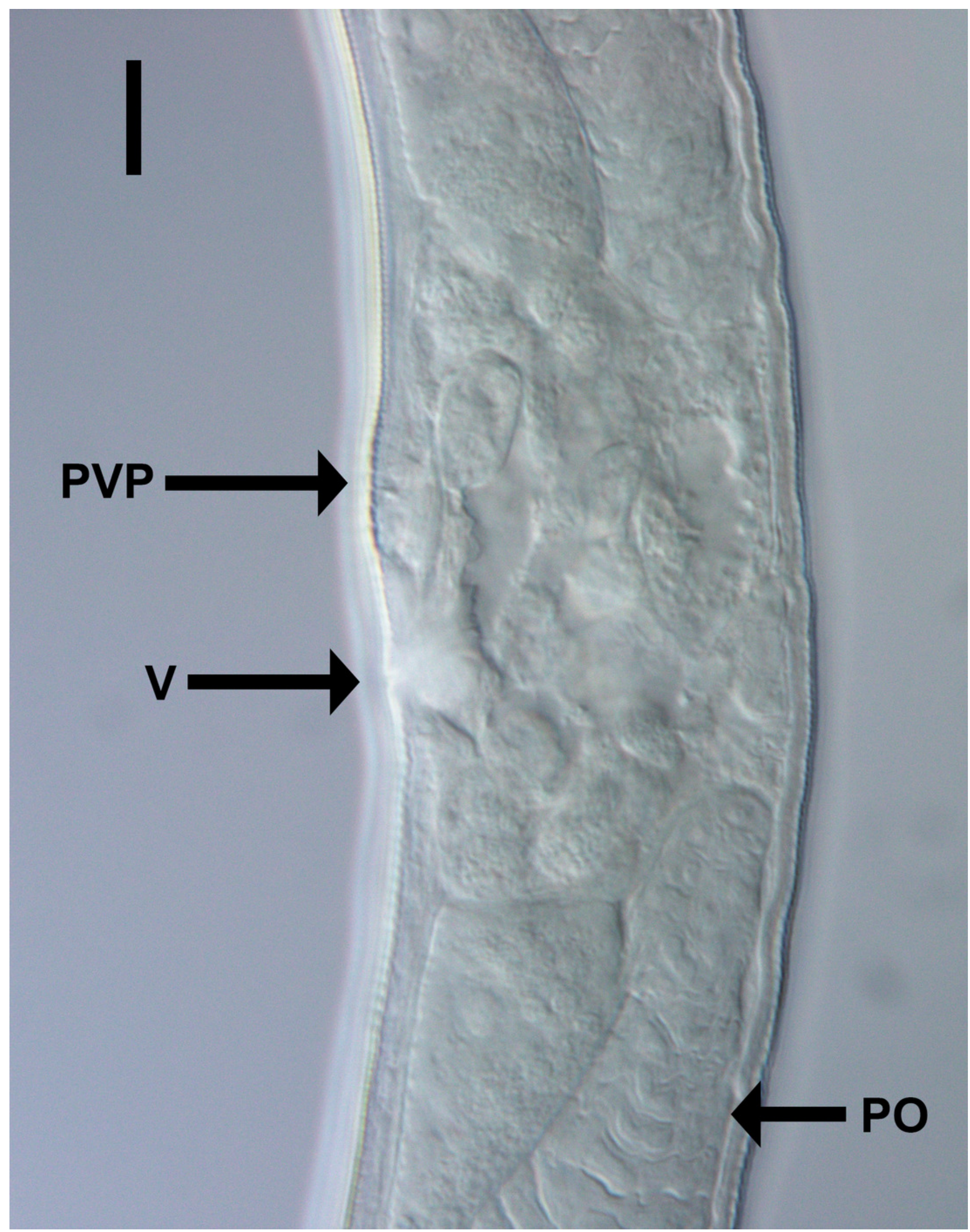

